Scientia Marina 71(2)

June 2007, 239-248, Barcelona (Spain)

ISSN: 0214-8358

\title{
Vitellogenesis, oocyte maturation pattern, spawning rhythm and spawning frequency in Otolithes ruber (Schneider, 1801) (Sciaenidae) in the Kuwaiti waters of the Arabian Gulf
}

\author{
STEPHEN DADZIE \\ Department of Biological Sciences, Kuwait University, P.O. Box 5969, Safat 13060, Kuwait. \\ E-mail: stevedadzie@hotmail.com
}

\begin{abstract}
SUMMARY: Vitellogenesis, oocyte maturation pattern, spawning rhythm, spawning frequency, batch fecundity and oocyte diameter-frequency distribution of the tigertooth croaker, Otolithes ruber (Schneider, 1801) in Kuwaiti waters were investigated from March 1999 to February 2000 and from January to May 2005, using histological and morphological methods. Oogenesis is described in four phases: vitellogenic, mature, spent and regressed. Vitellogenesis, in turn, is described in three classes: early vitellogenic, mid-vitellogenic and late vitellogenic. Development of the yolky oocyte is an asynchronous process resulting, by the time of oocyte maturation, in a clear differentiation between a ready batch of oocytes (ready for spawning) and a reserve pool. Consequently, $O$. ruber is capable of spawning multiple times during the reproductive season. Spawning frequency estimates, based on the final oocyte maturation (FOM) method indicated that the species spawns once every 2.8 days, while the estimates based on the post-ovulatory follicle (POF) method indicated a spawning every 2.2 days, during a 5-month spawning season lasting from January to May. Batch fecundity (BF) was significantly positively correlated with both ovary-free body weight (OFBW) $(\mathrm{p}<0.05)$ and standard length $(\mathrm{SL})(\mathrm{p}<0.05)$, but SL was a better predictor of $\mathrm{BF}\left(\mathrm{r}^{2}=33 \%\right)$ than was OFBW $\left(\mathrm{r}^{2}=19.9 \%\right)$. Batch fecundity was also significantly different between March and April $(\mathrm{p}<0.05)$ and March and May $(\mathrm{p}<0.05)$, but not between April and May $(\mathrm{p}>0.05)$. Relative batch fecundity was 716 eggs/g OFBW; thus, estimates for potential annual relative batch fecundity were 10024 eggs/g OFBW using the FOM method for spawning frequency estimation, and $7876 \mathrm{eggs} / \mathrm{g}$ OFBW using the POF method. The oocyte diameter-frequency distribution analysis revealed a multimodal distribution, confirming the evidence of multiple spawning.
\end{abstract}

Keywords: Otolithes ruber, Kuwait, reproduction, multiple spawning, spawning frequency.

RESUMEN: VITELOGÉNESIS, PATRÓN DE MADURACIÓN DE LOS OOCITOS Y RITMO Y FRECUENCIA DE PUESTA EN OTOLITHES RUBER (SCHNEIDER, 1801) (SCIAENIDAE) EN LAS AgUas KuwaitíES DEL GOLFO DE ARABia. - La vitelogénesis, el patrón de maduración de los oocitos, el ritmo y la frecuencia de puesta, fecundidad parcial y la distribución de frecuencias del diámetro de los oocitos de Otolithes ruber (Schneider, 1801) en aguas de Kuwait fueron investigados de marzo de 1999 a febrero de 2000 y de enero a mayo de 2005 usando métodos histológicos y morfológicos. Se describe la oogénesis en cuatro fases: vitelogenética, medio-vitelogenética y vitelogenética avanzada. El desarrollo del vitelo de los oocitos es un proceso asincrónico que, en el momento de la maduración del oocito, resulta en una clara diferenciación entre los oocitos hidratados (listos para la puesta) y los oocitos de reserve. Consecuentemente, $O$. rubber es capaz de poner múltiples veces a lo largo de la estación de puesta. Las estimas de frecuencia de puesta, basadas en el método de maduración final de los oocitos (FOM) indicaban que la especies pone una vez cada 2.8 días, mientras que la estimada en base al método de los folículos post-ovulatorios (POF) indicaba una puesta cada 2.2 días, durante una estación de puesta de 5 meses, que se extendía de enero a mayo. La fecundidad parcial (BF) estuvo positiva y significativamente correlacionada tanto con el peso del cuerpo (sin ovario) (OFBW) $(\mathrm{p}<0.05)$ como con la longitud estándar (SL) $(\mathrm{p}<0.05)$, sin embargo SL fue un mejor predictor de $\mathrm{BF}\left(\mathrm{r}^{2}=33 \%\right)$ que OFBW $\left(\mathrm{r}^{2}=19.9 \%\right)$. La fecundidad parcial fue también significativamente diferente entre marzo y abril $(\mathrm{p}<0.05)$ y marzo y mayo $(\mathrm{p}<0.05)$, pero no entre abril y mayo $(\mathrm{p}>0.05)$. La fecundidad parcial relativa fue 716 huevos/g OFBW; por tanto, la estima de la fecundidad parcial relativa anual potencial fue 10024 huevos/g OFBW, usando el método FOM para la estimación de la frecuencia de puesta y 7876 huevos/g OFBW, usando el método POF. El análisis de la distribución de frecuencias del diámetro del oocito revela una distribución multimodal, confirmando la evidencia de múltiple puesta.

Palabras clave: Otolithes ruber, Kuwait, reproducción, puesta múltiple, frecuencia de puesta. 


\section{INTRODUCTION}

Representatives of the family Sciaenidae are widely distributed in the tropical and subtropical waters of the Indian, Atlantic and Pacific oceans (Trewavas, 1977; Longhurst and Pauly, 1987). In the Kuwaiti waters of the Arabian Gulf, the sciaenid species, Otolithes ruber, plays an important role in the multispecies commercial fishery. Although the reproductive biology of many sciaenid species has been documented across the Gulf of Mexico (Merriner, 1976; DeMartini and Fountain, 1981; Lowerre-Barbieri et al., 1996; Brown-Peterson and Warren, 2001; Brown-Peterson et al., 2002), in South African waters (Griffiths, 1996, 1997; Fennessy, 2000) and in the West African coast of Benin (Pillai, 1983), only scant information is available from the Arabian Gulf and the Indo-West Pacific (Hussain and Abdullah, 1977; Abu-Hakima et al., 1983; Dadzie and Abou-Seedo, 2004). In Kuwaiti waters, Hussain and Abdullah (1977) described the monthly changes in the gonadosomatic index, while Abu-Hakima et al. (1983), in addition, reported on the histological changes during the seasonal maturation of the gonads. Dadzie and Abou-Seedo (2004) described the testicular structure and spawning only in the males. Apart from these reports, no other studies have been carried out on $O$. ruber either locally or regionally.

In view of the continued importance of $O$.ruber to the commercial fishery in Kuwait, a comprehensive study of the reproductive biology of the species is warranted. Thus, the purpose of this study was to investigate aspects of the reproductive biology of female tigertooth croaker, O. ruber, inhabiting the Kuwaiti waters in the northern Arabian Gulf. Specifically, the following tasks were undertaken: (1) histological investigation of the vitellogenic process during oogenesis, (2) description of oocyte maturation from the final oocyte maturation stage to the spawning stage, (3) description of the spawning rhythm, (4) estimation of the spawning frequency, (5) estimation of batch fecundity and (6) analysis of the oocyte diameter-frequency distribution during the spawning season.

\section{MATERIALS AND METHODS}

Fresh samples of Otolithes ruber were collected monthly from commercial gill-net catches in the

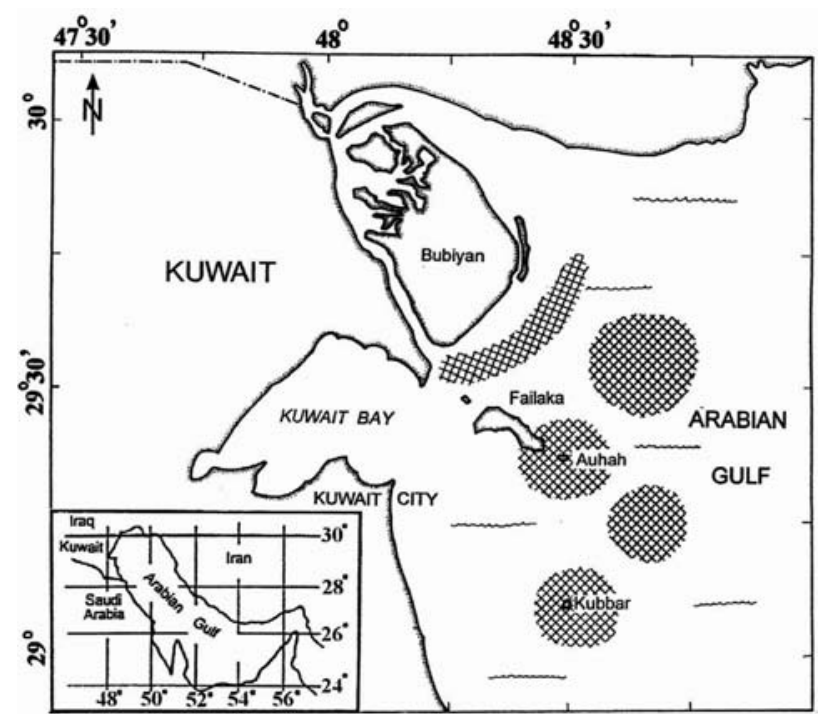

FIG. 1. - Map of Kuwaiti waters of the Arabian Gulf, showing the fishing areas (hatched).

northern part of the Kuwaiti waters of the Arabian Gulf (Fig. 1) during a 12-month sampling period, from March 1999 to February 2000. Supplementary samples were taken from the same area from January to May 2005, a period coinciding with spawning in the species in Kuwaiti waters. Salinity and water temperature values, which affect the reproductive patterns of sciaenids in other regions (Brown-Peterson and Warren, 2001; BrownPeterson et al., 2002), were compared for the two periods using the ANOVA test. The results indicated no differences between the two data sets for salinity $(p>0.05)$ or for water temperature $(p>0.05)$. The data were therefore merged to create one annual composite data-set to overcome low sample size. The nets used, measuring 1000-2500 m long, were laid at depths of 6-12 m. They were set at dawn between 0300 and $0500 \mathrm{~h}$, and raised for collection of the fishes between 1300 and $1400 \mathrm{~h}$. The vessels with $O$. ruber samples docked by $1530 \mathrm{~h}$, and study samples were obtained within $2 \mathrm{~h}$ and kept on ice. The total length $(\mathrm{cm})$, standard length $(\mathrm{cm})$ and body weight $(\mathrm{g})$ of each fish were recorded upon arrival in the laboratory. A total of 395 females were sampled during the study. All of them were dissected, and then the gonads were removed, weighed (to the nearest $0.001 \mathrm{~g}$ ) and fixed in Bouin's fixative for a minimum of $48 \mathrm{~h}$. Large ovaries were cut into pieces to facilitate penetration of the fixative. They were then dehydrated in alcohol, cleared in toluene and infiltrated with and embedded in paraffin wax. Sections of $5 \mu \mathrm{m}$ were stained in hematoxylin and 
TABLE 1. - Ovarian maturation classes for Otolithes ruber in Kuwaiti waters. FOM, final oocytes maturation; POF, post-ovulatory follicles.

\begin{tabular}{|c|c|c|c|c|c|c|c|c|c|c|c|c|}
\hline \multirow{2}{*}{$\begin{array}{l}\text { Ovarian maturation } \\
\text { class }\end{array}$} & \multicolumn{12}{|c|}{ Ovarian maturation classes (\%) } \\
\hline & Jan & Feb & Mar & Apr & May & Jun & Jul & Aug & Sep & Oct & Nov & Dec \\
\hline Immature & 0 & 0 & 0 & 0 & 10.2 & 70 & 100 & 100 & 100 & 100 & 100 & 63.7 \\
\hline Early vitellogenic & 0 & 0 & 0 & 0 & 6 & 0 & 0 & 0 & 0 & 0 & 0 & 36.3 \\
\hline Mid-vitellogenic & 54.1 & 15.2 & 0 & 0 & 0 & 0 & 0 & 0 & 0 & 0 & 0 & 0 \\
\hline Late vitellogenic & 16.7 & 45.5 & 11.4 & 0 & 0 & 0 & 0 & 0 & 0 & 0 & 0 & 0 \\
\hline Mature (FOM) & 4.2 & 15.2 & 68.2 & 14.6 & 2 & 0 & 0 & 0 & 0 & 0 & 0 & 0 \\
\hline Spent (POF) & 25 & 24.2 & 20.5 & 85.4 & 70 & 0 & 0 & 0 & 0 & 0 & 0 & 0 \\
\hline Regressed & 0 & 0 & 0 & 0 & 10.1 & 30 & 0 & 0 & 0 & 0 & 0 & 0 \\
\hline Sample size: & 24 & 33 & 44 & 55 & 49 & 16 & 30 & 31 & 35 & 50 & 17 & 11 \\
\hline
\end{tabular}

counterstained with eosin for studies of the histological changes during the maturation of the oocytes, with particular attention to vitellogenesis, final oocyte maturation and the spawning rhythm.

The developing oocytes were classified into different maturation classes and the monthly percentage frequency of occurrence of females in each class was determined (Table 1). Cell and nuclear sizes were measured during the process of development, using a Reichert research microscope. For this exercise, ovaries of five fish from each maturation class were examined, and in each ovary, oocyte and nuclear diameters were measured for 100 randomlyselected cells and the means determined. Only those oocytes which had been sectioned through the nucleus were measured. If the cell and nucleus were spherical, the diameters were measured, but if they were oval or irregular in shape, the mean of the longest and shortest axes were taken. This procedure has been shown to be representative of the true oocyte diameter (Foucher and Beamish, 1980).

Monthly spawning frequency was determined by calculating the percentage of females with postovulatory follicles (POF) and oocytes undergoing final oocyte maturation (FOM) from histological examination of ovarian tissues, following the procedures described by Hunter and Macewicz (1985). These provide estimates of fish in the population that will spawn within the next $12 \mathrm{~h}(\mathrm{FOM})$ or have just spawned in the past 12-24 h (POF). Spawning frequency was determined by dividing 100\% (representing all the fish in the sample) by the percentage of fish in the sample with FOM or POF in the ovaries. Multiplying the mean spawning frequency by the duration of the spawning season results in a potential total number of spawns during the year (Brown-Peterson et al., 2002).

Batch fecundity (BF), defined as the number of mature eggs in the most advanced size class, and presumably representing the number of eggs spawned at one time, was determined from ripe females during January-May. Batch fecundity was estimated for 50 fish by the gravimetric method (Kipling and Frost, 1969), based on five 1-g subsamples. The relationship of BF to ovary-free body weight (OFBW) and standard length (SL) was determined by regression analysis to establish which of the two parameters is a better predictor of $\mathrm{BF}$. Relative batch fecundity (RBF), defined as the number of eggs per gram OFBW was also determined from ripe females from March, the peak of spawning, to May. The potential annual RBF was estimated, following Karlou-Riga and Economidis (1997), by multiplying the RBF by the potential annual spawning frequency.

Ova diameter-frequency distributions from Gilson's fluid-preserved ovaries collected from the peak spawning period in March, through to May, were determined with the view to further confirming the spawning rhythm and the spawning type. Ripe females, judged visually by the yellowish or pinkish-pale colour of the ovaries and relatively larger, strippable-size oocytes, were used for this study. Five sub-samples were taken from each ovary, and approximately 100 oocytes from each sub-sample were measured using an eyepiece graticule fitted on a stereomicroscope (Cambridge Instruments). Care was taken to ensure that only viable cells were measured. Percentage frequency of occurrence of oocytes in different size classes in monthly samples were plotted as histograms. Since all oocytes $<100$ $\mu \mathrm{m}$ belonged to the reserve pool, they were eliminated from the counts.

\section{RESULTS}

The present report on oogenesis in $O$. ruber is restricted to a brief characterisation of four phases: vitellogenesis, mature, spent and regressed. The per- 

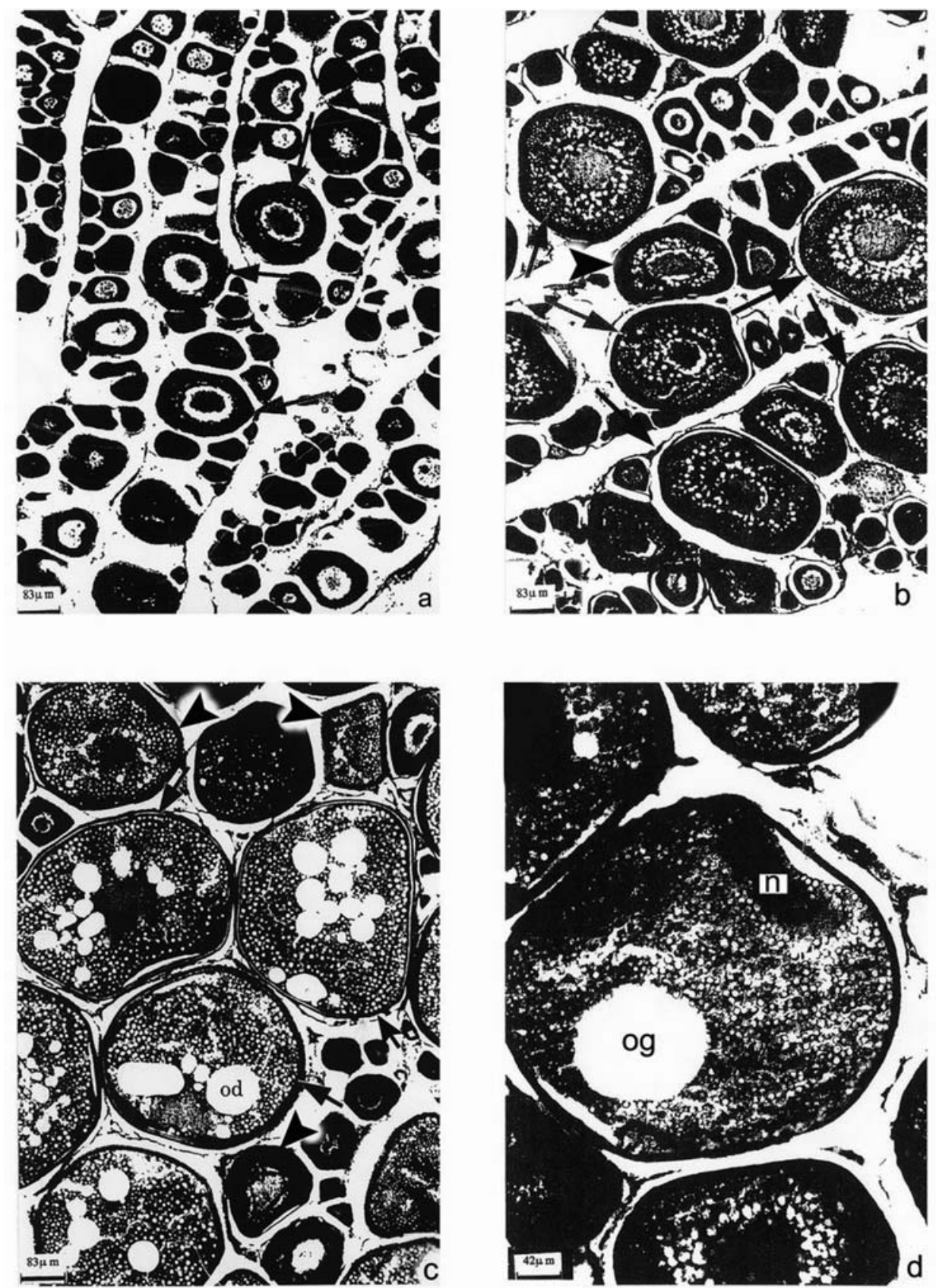

FIG. 2. - Sections of ovaries of Otolithes ruber, showing: (a) early vitellogenic class oocytes (arrows); (b) mid-vitellogenic class oocytes (arrows) and early vitellogenic class oocytes (arrow-heads); (c) late vitellogenic class oocytes (arrows), mid-vitellogenic class and early vitellogenic class oocytes (arrow-heads) and an oil drop (od); (d) mature oocyte with migrated nucleus (n) and an oil globule (og).

centage of females in monthly maturity classes, including the immature class, is presented in Table 1. The immature class include females with oocytes in the oogonial and perinucleolar stages.

\section{Vitellogenesis}

The vitellogenic phase of oocyte development of $O$. ruber is divided into three classes: (i) early vitellogenic, (ii) mid-vitellogenic and (iii) late vitellogenic.

\section{Early vitellogenic class}

The first signs of vitellogenesis are noticed in December when tiny oil vesicles, recognised on histological slides as empty vacuoles, are observed within the cytoplasm of the oocytes. The latter measure $114.7 \pm 17.5 \mu \mathrm{m}$, and $57.3 \pm 8.9 \mu \mathrm{m}$ for the nucleus (Fig. 2a). The oocytes enter a period of growth during which the oil vesicles increase in size and quantity. 


\section{Mid-vitellogenic class}

The primary characteristic of the mid-vitellogenic class oocytes is the appearance in them of small $(5.6 \pm 2 \mu \mathrm{m})$, eosinophilic yolk granules in the outer layer of the cytoplasm, which then spread centripetally. The oil vesicles continue to increase in quantity and size $(12.6 \pm 0.9 \mu \mathrm{m})$, and take up the entire cytoplasm except for the peripheral layer which is taken up by the yolk granules. A rapid increase in size of the oocytes is observed and the latter are now surrounded by a layer of connective tissue cells with spindle-shaped nuclei. Yolk granules increase in quantity and size $(10.8 \pm 0.9 \mu \mathrm{m})$, and become globular. Oil vesicles further increase in size $(20.8 \pm 1.5 \mu \mathrm{m})$ and begin to coalesce around the nucleus which still lies at the centre of the oocyte. Yolk and oil are now intermingled throughout the cytoplasm. The chorion, measuring $7.6 \pm 0.5$ $\mu \mathrm{m}$ thick, with clear, visible striations, makes its appearance around the oocyte. The latter increases in size to $352.9 \pm 5.8 \mu \mathrm{m}$, and $99.2 \pm 2.4 \mu \mathrm{m}$ for the nucleus (Fig. 2b). Apart from the mid-vitellogenic class oocytes, early vitellogenic ones continue to be recruited from immature class oocytes.

\section{Late vitellogenic class}

The cytoplasm is packed with numerous eosinophilic yolk globules. As the yolk globules increase in size $(12.8 \pm 0.74 \mu \mathrm{m})$, a further substantial coalescence of the oil vesicles takes place, resulting in the formation of considerably larger oil droplets, measuring $49.5 \pm 4.3 \mu \mathrm{m}$, surrounding the nucleus and pressing tightly to it, tending to displace it from the centre. Oocyte and nuclear sizes increase further to $396.5 \pm 3.4 \mu \mathrm{m}$ and $111.9 \pm 2 \mu \mathrm{m}$, respectively, and the nucleus now attains an irregular shape. The zona radiata, now differentiated into an outer eosinophilic layer, the zona radiata externa, with faint radial striations, and an inner basophilic layer, the zona radiata interna, with more prominent striations, shows a further increase in thickness to $10.1 \pm 1.2 \mu \mathrm{m}$. No further increase in size of the oocyte is observed, although oil droplets continue to coalesce into larger and larger oil drops (Fig. 2c). These events, resulting in the attainment of the maximum size of the oocyte, are reliable criteria for the completion of vitellogenesis. The oocytes, from this stage onwards are said to be in the final oocyte maturation phase (FOM). However, oocytes in different vitellogenic classes continue to be elaborated in the ovaries and undergo vitellogenesis asynchronously. These observations were made in the ovaries of the January samples, indicating that oocyte maturation in $O$. ruber is an accelerated process lasting only one month from the start of vitellogenesis.

\section{Mature phase}

During oocyte maturation, oil drops coalesce into a single globule, measuring $135.9 \pm 2.38 \mu \mathrm{m}$ in diameter, situated either at the vegetative pole or at the centre of the ovary, thus completely displacing the nucleus which migrates from the centre of the cell to the animal pole where it elongates and finally dissolves (Fig. 2d). Yolk globules also coalesce into a homogeneous mass and the oocytes become transparent. After completion of homogenisation, hydration of the oocytes begins, leading to ovulation. Mature oocytes in migratory-nuclear and yolk homogenisation stages were first observed in January, indicating imminent spawning.

\section{Spent phase}

During the spent phase, the ovary is characterised by the presence of different generations of POF, their number being a rough reflection of the number of times the female has spawned. Different classes of vitellogenic oocytes are also present (Fig. 3a).

\section{Regressed phase}

The regressed ovary presents many oocytes and follicles undergoing resorption, as well as immature, non-yolky oocytes broadcast within the organ.

\section{Spawning rhythm}

The main spawning in $O$. ruber begins in January and ends in April, although 4\% of the specimens were spawning in May, as evidenced by the presence of FOM oocytes (Table 2). Histological evidence showed that females in the late vitellogenic phase sampled in January contained oocytes in different developmental classes. This represents a typical asynchronous type of ovarian development. The ovaries of partiallyspent females sampled in January and February contained POF and a wide variety of vitellogenic 

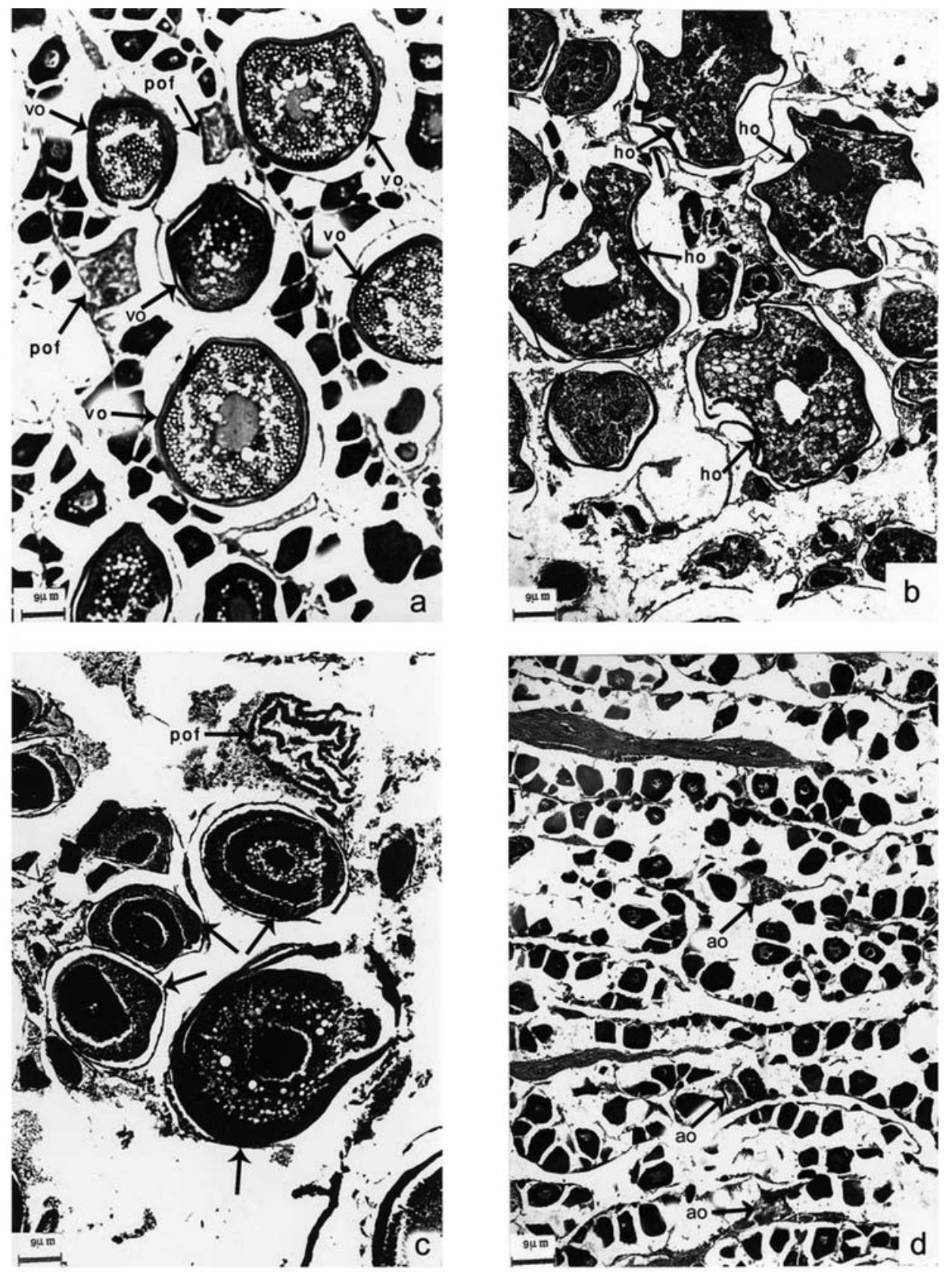

FIG. 3. - Sections of ovaries of Otolithes ruber, showing: (a) different generations of post-ovulatory follicles (pof) and different classes of vitellogenic oocytes (vo); (b) hydrated oocytes (ho); (c) a large post-ovulatory follicle (pof) and oocytes undergoing post-mortem degeneration (arrows); (d) an advanced regressed ovary filled with immature, non-yolky oocytes and few remnants of late stage atretic oocytes (ao).

oocytes (Fig. 3a), indicating a recent spawning event and the potential for additional batches of eggs to be released, confirming that $O$. ruber is a typical multiple spawner. Sequential ovulation of the FOM from the additional batches of late vitellogenic class oocytes occurs synchronously and they form the subsequent batches of eggs which are spawned later. After repeated spawnings, POF from distinctly different generations, indicating successive spawnings, are present in the ovaries.
The height of spawning occurred in March, as the majority of the specimens $(68.2 \%)$ exhibited ovaries packed with FOM (Fig. 3b). The histological features of the April samples suggested strongly that spawning was drawing to a close after the peak spawning the month before. This is evidenced by the presence of different generations of POF, including large ones, suggesting recent release of another batch of eggs, and oocytes undergoing post mortem degeneration (Fig. 3c). In addition, rela- 
TABLE 2. - Spawning frequency of Otolithes ruber in Kuwaiti waters; N, number of fish sampled; FOM, number of fish in final oocyte maturation class; POF, number of fish in post-ovulatory fol licle class.

\begin{tabular}{lccccc}
\hline Month & N & FOM & POF & \multicolumn{2}{c}{$\begin{array}{c}\text { Monthly spawnings(\%) } \\
\text { FOM }\end{array}$} \\
& & & & POF \\
\hline January & 24 & 5 & 6 & 20.8 & 25 \\
February & 33 & 20 & 8 & 60.6 & 24.2 \\
March & 44 & 35 & 9 & 79.5 & 20.5 \\
April & 55 & 8 & 47 & 14.5 & 85.5 \\
May & 49 & 2 & 35 & 4 & 71.4 \\
Mean \% & & & & 35.9 & 45.3 \\
\hline
\end{tabular}

tively few of the ovaries of the April samples $(15 \%)$ revealed the presence of FOM (Table 2). Reorganisation in the regressed ovary was fairly rapid at this time as, apart from the very few remnants of late stage atretic oocytes, the overwhelming majority of the samples contained numerous immature, non-yolky oocytes (Fig. 3d).

\section{Spawning frequency}

During the spawning period, (January-May), a total of 205 ovaries were sectioned, of which 69 were in the FOM stage and 105 in the POF stage (Table 2). The mean monthly spawning frequency was $35.5 \%$ using the FOM method and $45.3 \%$ using the POF method, indicating spawning frequencies of 2.8 days and 2.2 days respectively, which were not significantly different from each other (ANOVA, $\mathrm{p}<0.05$ ). These figures give a potential number of spawns during the year of 14 and 11, using the FOM and POF methods, respectively.

\section{Batch fecundity}

A total of 50 mature females ranging from 37 to $55 \mathrm{~cm} \mathrm{SL}$, with corresponding weights of 739.8 and $210 \mathrm{~g}$, respectively, were used for the batch fecundity analysis. Batch fecundity ranged from a minimum of 190000 eggs for a $40 \mathrm{~cm}$ SL fish weighing 977.6 $\mathrm{g}$, to a maximum of $1753247 \mathrm{eggs}$ for a $50 \mathrm{~cm} \mathrm{SL}$ fish weighing $1677.8 \mathrm{~g}$, with a mean of 779737 eggs. Batch fecundity was significantly positively correlated with both OFBW $(\mathrm{p}<0.05)$ (Fig. 4a) and SL $(p<0.05)$ (Fig. 4b). SL was a better predictor of $\mathrm{BF}\left(\mathrm{r}^{2}=33 \%\right)$ than was OFBW $\left(\mathrm{r}^{2}=19.9 \%\right)$. A significant difference was found in BF between March, the height of the spawning season, and April $(\mathrm{p}<0.05)$ and between March and May $(\mathrm{p}<0.05)$, but not between April and May ( $>>0.05$ ) (Fig. 5). The
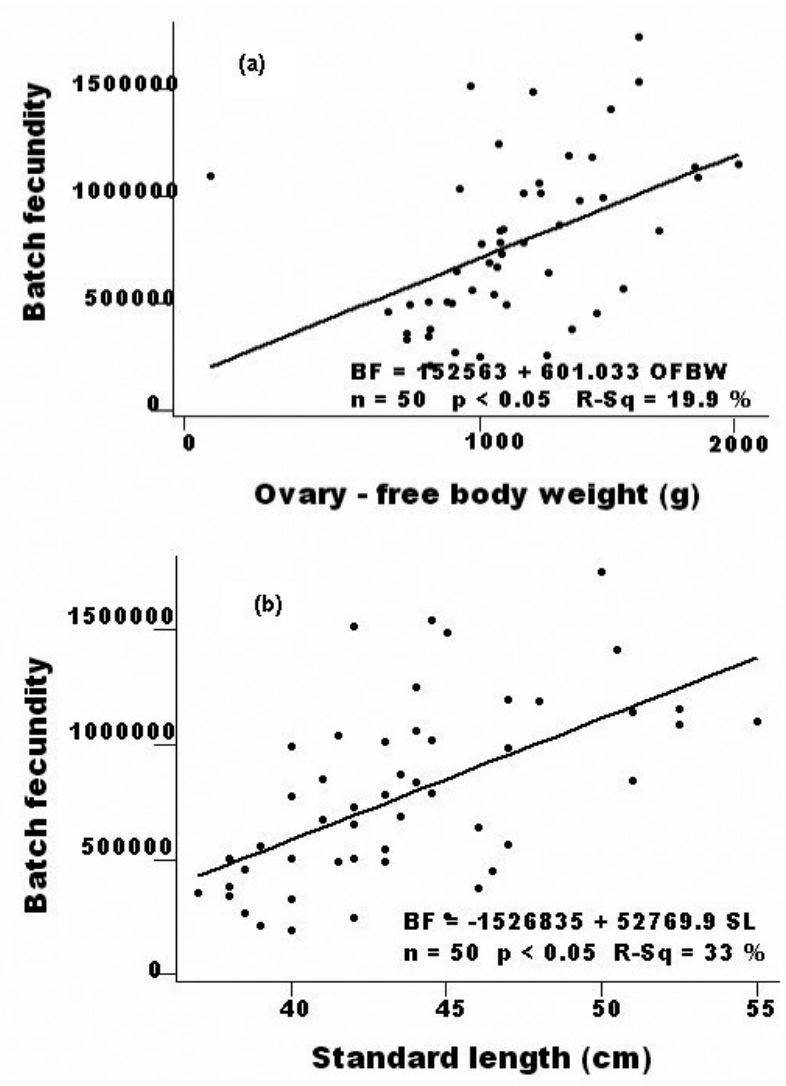

FIG. 4. - Relationship between batch fecundity and: (a) ovary-free body weight and (b) standard length in Otolithes ruber. Note: BF, batch fecundity; OFBW, ovary-free body weight; SL, standard length; R-Sq, coefficient of determination.

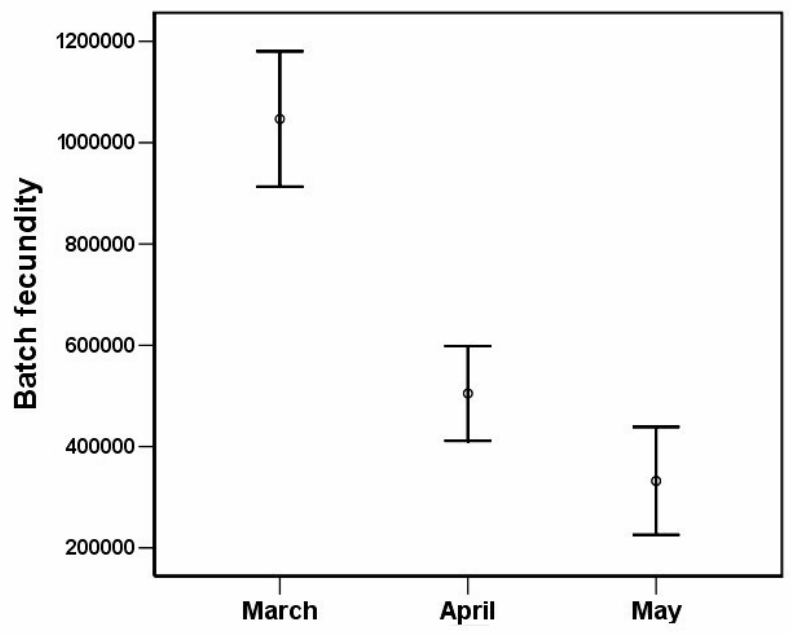

FIG. 5. - Monthly variations in relative batch fecundity in Otolithes ruber. The centre circles represent the mean, while the vertical bars indicate $95 \%$ C.I.

relative batch fecundity was 716 eggs/g OFBW. Therefore, the potential annual relative fecundity is 10024 eggs/g OFBW using the FOM method of spawning frequency estimation, and 7876 using the POF method. 


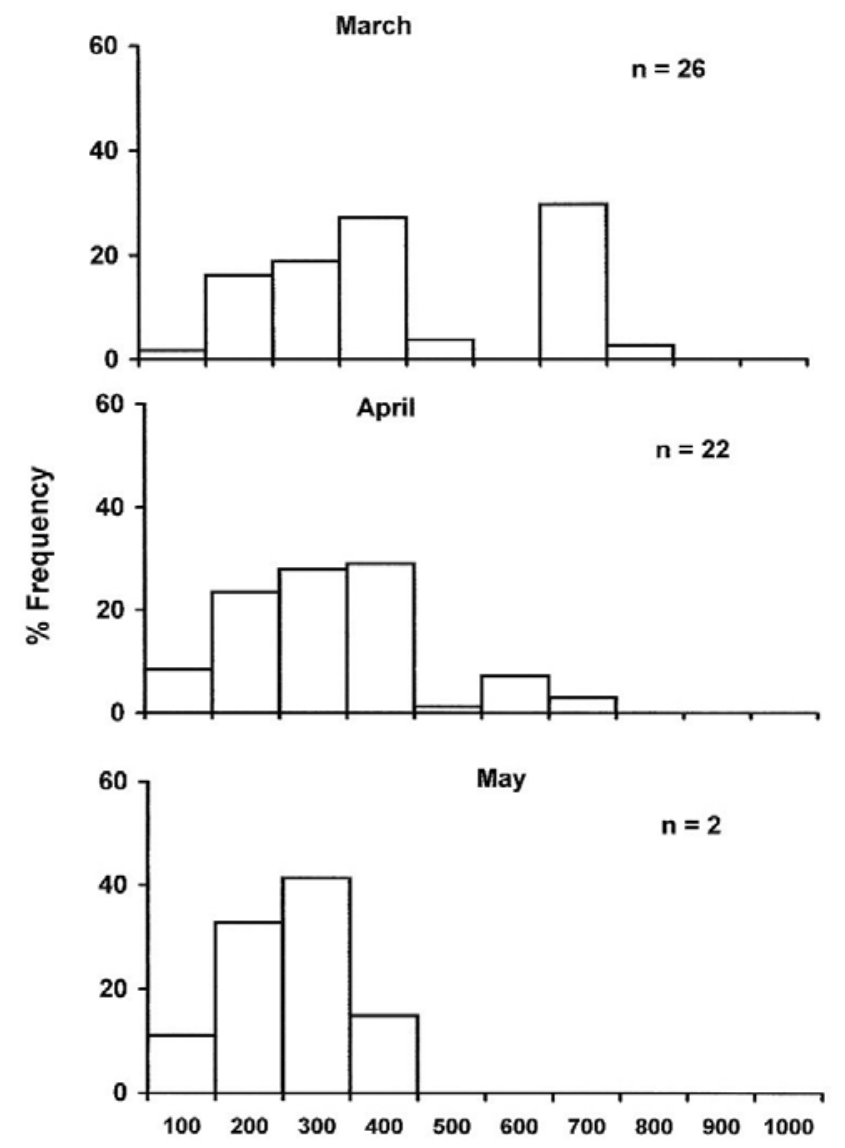

Oocyte diameter $(\mu \mathrm{m})$

FIG. 6. - Oocyte diameter-frequency distribution for Gilson's fluidpreserved eggs of Otolithes ruber sampled during the spawning season. $\mathrm{n}=$ number of fish.

\section{Oocyte diameter-frequency distribution}

In female $O$. ruber sampled at the height of spawning in March, the oocytes of the mature females exhibited three modes in diameter-frequency distribution, as revealed by examination of Gilson's fluid-preserved whole eggs, as follows: the most advanced group measured $700-800 \mu \mathrm{m}$, the intermediate mode measured $400-500 \mu \mathrm{m}$, and the remaining mode measured 100-300 $\mu \mathrm{m}$ (Fig. 6). The most advanced size class of eggs was clearly distinguishable and did not overlap in size with the other two size classes.

Examination of the eggs using a stereomicroscope revealed three egg-types that correspond, more-or-less, with the modes found in the frequency distributions of oocyte diameters. The most advanced size class of cells was that of ripe eggs and consisted of two types: (a) spherical, hydrated, hya- line and golden, with gelatinous threads coiled around them, characteristic of hydration stage oocytes and (b) golden and translucent at the animal pole, characteristic of migratory-nuclear stage oocytes. The intermediate group, made up of cells with dense, dark and compact yolk, were maturing, vitellogenic oocytes, while the smaller mode did not differ much in appearance from the former, except by size.

In April, a similar modal pattern, except for a considerable overlap in modes between the intermediate and smallest size classes, was evident. However, the most advanced group continued to be distinct, but at a reduced size class $-500-700 \mu \mathrm{m}$. By May, most of the large size class eggs are shed, and the oocyte diameter-frequency distribution reveals only a single mode, at 100-400 $\mu \mathrm{m}$. Generally, there is a reduction in the size of eggs spawned as spawning progresses, from $800 \mu \mathrm{m}$ in March, to $400 \mu \mathrm{m}$ in May.

\section{DISCUSSION}

Nearly two decades after the pioneering studies on reproduction in Otolithes ruber (Hussain and Abdullah, 1977; Abu-Hakima et al., 1983), evidence is presented in the present study to support the earlier findings that the main spawning season of the species in Kuwaiti waters is from January to April. However, this study has also revealed that a small proportion of the stocks continue spawning into May. The present findings are also in conformity with the gonadosomatic index profiles depicted in Abu-Hakima et al. (1983), in terms of the acceleration of the process of vitellogenesis. Once initiated in December, vitellogenesis proceeds very rapidly, leading to maturation and the onset of spawning in January. Accelerated vitellogenesis and extended spawning durations could be common features of the sciaenids from a latitudinally similar (sub-tropical) but geographically discrete range (Fennessy, 2000; Brown-Peterson et al., 2002).

Vitellogenesis in $O$. ruber is an asynchronous process. During the first part of the process, development of oocytes is markedly asynchronous, so oocytes of different sizes, corresponding to different vitellogenic classes, are present in the ovaries at the same time. By the end of the vitellogenic phase, due to the asynchrony in development, a clear differentiation between oocytes meant for the first spawning 
(FOM, or the ready batch) and those for subsequent spawnings (late vitellogenic, mid-vitellogenic and early vitellogenic classes, or the reserve pool), becomes discernible. Discussed together with the data on oocyte diameter-frequency distribution, as the oocytes pass into the maturation phase, the ready batch becomes increasingly differentiated into two types of cells. One includes oocytes in the migratory-nuclear stage, and the second includes oocytes in the yolk homogenisation and hydration stage. These two maturation phase oocytes are probably shed together during spawning as one batch, since transformation of migratory-nuclear oocytes into yolk homogenisation and hydration ones during oocyte maturation in teleosts is usually quite rapid and is accomplished within $24 \mathrm{~h}$ (Hunter and Macewicz, 1985; Selman and Wallace, 1989; Karlou-Riga and Economidis, 1997).

The oocyte diameter-frequency distribution data revealed no distinct hiatus between the maturing and immature size-class ova (the reserve pool) due to their asynchronous development. However, by the end of vitellogenesis, as the asynchrony evens out, and the ova constituting the ready batch are ovulated, the cells forming the intermediate mode apparently become distinctly differentiated into a new ready batch for the spawning of the next batch of eggs. Meanwhile, part of the smaller size class, as a result of asynchronous development, recruits into the intermediate pool which, in turn, transforms into the ready batch for the spawning of the next batch of eggs. These sequential or rhythmic events continue until the last batch of eggs is shed. These observations typify multiple spawning reported in a number of teleosts (Bagenal and Braum, 1971; Jones, 1978; Hempell, 1979; DeMartini and Fountain, 1981; Hunter and Leong, 1981; Conover, 1985; Hunter et al., 1986, 1992; Lowerre-Barbieri et al., 1996; Brown-Peterson and Warren, 2001; Almatar et al., 2004).

The FOM and POF methods for estimating spawning frequencies have been used as a tool for comparing dynamics of egg production in species with a wide latitudinal distribution, in species inhabiting different regions of the same water-bodies, in species with different reproductive seasons, and in year-to-year differences within a species (Hunter and Goldberg, 1980; Conover, 1985; Hunter and Macewicz, 1985; Hunter et al., 1992; BrownPeterson and Thomas, 1988; Karlou-Riga and Economidis, 1997; Brown-Peterson and Warren,
2001; Brown-Peterson et al., 2002). These studies were conducted mainly on fishes inhabiting North American waters. Apart from Almatar et al. (2004) who reported on the spawning frequency of Pampus argenteus in Kuwaiti waters, no other study has been undertaken either locally or regionally. From the present study, with spawning occurring in females on average every 2.8 days according to the FOM method of estimation, and every 2.2 days as revealed by the POF method, it may be concluded that the potential annual number of spawns in $O$. ruber is 11 and 14, according to the FOM and POF methods, respectively.

From the results of this study, it may be concluded that vitellogenesis in $O$. ruber is an asynchronous process resulting, at the time of oocyte maturation, in the formation of different classes of oocytes. Spawning is a rhythmic activity lasting five months during which eggs are liberated once every 2.2 to 2.8 days, reflecting the multiple spawning habits of the species. Oocyte diameter-frequency distribution revealed a multimodal pattern, in further confirmation of multiple spawning. Finally, batch fecundity was a function of both ovary-free body weight and fish standard length.

\section{ACKNOWLEDGEMENTS}

I am grateful to Mrs. Thecla Gomes for histological processing of the gonadal tissues, Mrs. Jalaja V. Sukumaran, for egg counts and measurements, and plotting the histograms, Mrs. Reshmy Sobha, for statistical analysis of the data and Mr. Abd ElMennem Saleh, for sample collection and laboratory assistance. Dr. Fadwa Abou-Seedo assisted with removal of the gonads. I also wish to acknowledge Dr. Majed Al-Naqeeb for provision of photomicrographic facilities. This study was partly funded by the College of Graduate Studies, Kuwait University.

\section{REFERENCES}

Abu-Hakima, R., C. El-Zahr and M. Shoushani. - 1983. The reproductive biology of Otolithes argenteus (Cuvier and Valenciennes) (Family Sciaenidae) in Kuwaiti waters. Kuwait Inst. Sci. Res. Rep., 1-17.

Almatar, S.M., K.P. Lone, T.S. Abu-Rezq and A.A. Yusef. - 2004. Spawning frequency, fecundity, egg weight and spawning type of silver pomfret, Pampus argenteus (Euphrasen) (Stromateidae), in Kuwait waters. J. Appl.Ichthyol., 20: 176-188.

Bagenal, T.B. and E. Braum. - 1971. Eggs and early life history. In: W.E. Richer (ed.), Methods for assessment of fish production in fresh waters, pp. 166-198. IBP Handbook (2 ${ }^{\text {nd }}$ ed.). Blackwell 
Scientific Publication, Oxford.

Brown-Peterson, N.J., M.S. Peterson, D.L. Niedland, M.D Murphy, R.G. Taylor and J.R. Warren. - 2002. Reproductive biology of female spotted seatrout, Cynoscion nebulosus, in the Gulf of Mexico: differences among estuaries? Environ. Biol. Fish., 63: 405-415.

Brown-Peterson, N. and P. Thomas. - 1988. Differing reproductive life histories between temperate and subtropical groups of Cynoscion nebulosus. Cont. Mar. Sci., 30(Suppl.): 71-78.

Brown-Peterson, N.J and J.W. Warren. - 2001. The reproductive biology of the spotted seatrout, Cynoscion nebulosus, along the Mississippi Gulf Coast. Gulf Mex. Sci., 2001: 61-73.

Conover, D.O. - 1985. Field and laboratory assessment of patterns in fecundity of a multiple spawning fish: the Atlantic silverside, Menidia menidia. Fish. Bull., 83: 331-341.

Dadzie, S. and F. Abou-Seedo. - 2004. Testicular structure and spawning cycle in the silvery croaker, Otolithes ruber (Perciformes: Sciaenidae) in the Kuwaiti waters of the Arabian Gulf. Ichthyol. Res., 51: 263-268.

DeMartini, E.E. and R.K. Fountain. - 1981. Ovarian cycling frequency and batch fecundity in the queenfish, Seriphus politus: Attributes representative of serial spawning fishes. Fish. Bull., 79: 547-560.

Fennessy, F.T - 2000. Aspects of the biology of four species of Sciaenidae from the East Coast of South Africa. Est. Coast. Shelf Sci., 50: 259-269.

Foucher, R.P. and R.J. Beamish. - 1980. Production of nonviable oocyte by Pacific hake, (Merluccius productus). Can. J. Fish. Aquat. Sci., 37: 41-48.

Griffiths, M.H. - 1996. Life history of the dusky kob Argyrosomus japonicus (Sciaenidae) off the East coast of South Africa. S. Afr. J. mar. Sci., 17:135-154.

Griffiths, M.H. -1997 . The life history and stock separation of the silver kob, Argyrosomus inodorus, in South African waters. Fish. Bull., 95: 47-67.

Hempell, G. - 1979. Early life history of marine life. Univ. Wash. Press, Seattle.

Hunter, J.R and S. Goldberg - 1980. Spawning incidence and batch fecundity in northern anchovy, Engraulis mordax. Fish. Bull., 77: 641-652

Hunter, J.R. and R. Leong. - 1981. The spawning energetics of female northern anchovy, Engraulis mordax. Fish. Bull., 79: 215-230.
Hunter, J.R. and Macewicz, B.J. - 1985. Rates of atresia in the ovary of captive and wild northern anchovy, Engraulis mordax. Fish. Bull., 83: 119-136.

Hunter, J.R., B.J. Macewicz, N.C. Lo and C.A. Kimbrell. - 1992. Fecundity, spawning, and maturity of female Dover sole, Microstomus pacificus, with an evaluation of assumptions and precision. Fish. Bull., 90: 101-128.

Hunter, J.R., B.J. Macewicz and J.R. Sibert. - 1986. The spawning frequency of skipjack tuna, Katsuwonus pelamis, from the South Pacific. Fish. Bull., 84: 895-903.

Hussain, N.A. and M.A.S. Abdullah. - 1977. The length-weight relationship, spawning season and food habits of six commercial fishes in Kuwaiti waters. Indian J. Fish., 24: 181-194.

Jones, R.E. - 1978. Ovarian cycles in non-mammalian vertebrates. In: R.E Jones (ed.), The vertebrate ovary, pp. 731-762. Plenum Press, New York.

Karlou-Riga, C. and P.S. Economidis. - 1997. Spawning frequency and batch fecundity of horse mackerel, Trachurus trachurus (L.), in the Soronikos Gulf (Greece). J. Appl. Ichthyol., 13: 97104 .

Kipling, C. and W.E.F. Frost. - 1969. Variation of fecundity of pike Esox lucius (L.) in Windmere. J. Fish Biol., 1: 221-237.

Longhurst, A.R. and D. Pauly. - 1987. Ecology of tropical oceans. Academic Press, Inc., San Diego.

Lowerre-Barbieri, S.K., M.E. Chittenden, Jr. and L.R. Barbieri. 1996. The multiple spawning pattern of weakfish in the Chesapeake Bay and Middle Atlantic Bight. J. Fish. Biol., 48: 1139-1163.

Merriner, J.V. - 1976. Aspects of the reproductive biology of the weakfish, Cynoscion regalis (Sciaenidae), in North Carolina. Fish. Bull., 74: 18-26.

Pillai, P.K.M. - 1983. On the biometry, food and feeding habits and spawning habits of Otolithes ruber (Schneider) from Porto Novo. Indian J. Fish., 30: 69-73.

Selman, K and R.A. Wallace. - 1989. Cellular aspect of oocyte growth in teleosts. Zool. Sci., 6: 211-231.

Trewavas, E. - 1977. The sciaenid fishes (croakers or drums) of the Indo-West Pacific. Trans. Zool. Soc. Lond., 33: 253-541.

Scient. ed.: F. Piferrer.

Received April 18, 2006. Accepted February 19, 2007.

Published online May 18, 2007. 